\title{
WAITING
}

The pond is working a plan

Beneath the floor of dark glaze,

Sorting tranquil tides

Rambling like water snakes,

Combing out old hairs of sunlight

Tangling fish.

One has to wait a long time

Before the pond settles

And hears its dark gate

Closing at the shore.

Then stones retire

Into their pallor.

Obediently trees bend.

Through the soft hall of light,

Dusk sinks down and drinks.

\section{SHELTER FOREST}

1

The leaves are turning

Into spiders of dusk.

Water bugs walk along

The glazed moon.

A thousand wings begin to flutter In their simple rooms in the trees.

A star yawns

Shaking itself downstream.

2

I lie down

And hear water flow

Through green moss

Like an honest man's life. 